\title{
Analisa Kinerja Keuangan pada PT. Garuda Indonesia,Tbk
}

\author{
Reina Damayanti ${ }^{1}$, Hendry Saladin², Juni Darwin ${ }^{3}$ \\ ${ }^{1}$ Manajemen, Fakultas Ekonomi, Univ.PGRI Palembang, reinadamayanti@univpgri-palembang.ac.id \\ ${ }^{2}$ Akuntansi, Fakultas Ekonomi, Univ.PGRI Palembang h saladin@univpgri-palembang.ic.id \\ ${ }^{3}$ Akuntansi, Fakultas Ekonomi, Univ. PGRI Palembang junidarwin@univpgri-palembang.ic.id
}

\begin{abstract}
ABSTRAK
Tujuan Penelitian ini adalah untuk mengetahui tingkat kesehatan dalam Kinerja Keuangan Perusahaan BUMN PT.Garuda,Tbk khususnya pada penilaian rasio berdasarkan Surat Keputusan Mentri BUMN No.KEP-100/KBU/2002 perusahaan periode 2013-2017. Alat analisis yang digunakan dalam penelitian ini adalah metode data deskriptif kuantitatif menggunakan rasio Keputusan Mentri BUMN No.KEP100/KBU/2002 dengan menganalisa laporan keuangan pada tahun 2013 sampai tahun 2017. Berdasarkan hasil analisis dan pembahasan Kinerja Keuangan Perusahaan BUMN PT.Garuda,Tbk pada tahun 2013 sampai dengan 2017. Nilai rasio dan total skor untuk tahun 2013 Rasio ROE (1\%), ROI (0,38\%), Kas (48,30\%), Lancar (83,25\%), CP (15 hari), PP (9 hari), TATO $(129 \%)$, TMS thd TA $(37,82 \%)$ total skor 34, tahun 2014 Rasio ROE $(-40,58 \%)$, ROI $(-12,00 \%)$, Kas (35,61\%), Lancar $(66,47 \%)$, CP (12 hari), PP (8 hari), TATO (161\%), TMS thd TA $(29,56 \%)$ total skor 28.29, Tahun 2015 Rasio ROE (8,20\%), ROI (2,36\%), Kas (43,48\%), Lancar (84,28\%), CP (13 hari), PP (9 hari), TATO $(115 \%)$, TMS thd TA $(28,72 \%)$ total skor 41,75 . Tahun 2016 Rasio ROE $(0,93 \%)$, ROI (0,25\%), Kas (37,01\%), Lancar (74,52\%), CP (20 hari), PP (10 hari), TATO (103\%), TMS thd TA $(27,02 \%)$ total skor 30,25 . Tahun 2017 Rasio ROE (-72,41\%), ROI (-18,04\%), Kas (15,97\%), Lancar (51,34\%), CP (24 hari), PP (11 hari), TATO(111\%), TMS thd TA $(24,91 \%)$ total skor $25,75$.
\end{abstract}

Kata kunci : kinerja keuangan, rasio KepMen BUMN No.KEP100/KBU/2002

\section{A. PENDAHULUAN}

Pertumbuhan jumlah pengguna sektor transportasi yang kian signifikan merupakan suatu tantangan sekaligus peluang bagi industri transfortasi dalam mengembangkan bisnisnya. Berdasarkan data biro sensus Amerika, Indonesia memiliki sekitar 250 juta jiwa penduduk, yang menjadikan Indonesia sebagai Negara keempat dengan jumlah penduduk terbanyak di dunia setelah Cina, India, dan Amerika Serikat besarnya jumlah penduduk Indonesia sesungguhnya menghasilkan sebuah permintaan yang tinggi akan sarana dan prasarana kehidupan yang memadai, termasuk sarana transportasi. Namun yang terjadi adalah hingga saat ini Indonesia masih mengalami kompleksitas dalam membangun sarana dan prasarana transfortasi itu sendiri, baik dalam Sektor Trasportasi Darat, Udara, maupun Lautan, hal tersebut akan menarik para investor untuk menanamkan modal, sektor transfortasi merupakan salah satu sub sektor dari infrastruktur di Bursa Efek Indonesia.

Bursa efek atau bursa saham
adalah sebuah pasar yang berhubungan dengan pembelian dan penjualan efek perusahaan yang sedah terdaftar dibursa itu. Bursa efek tersebut, bersama-sama dengan pasar uang merupakan sumber utama permodalan eksternal bagi perusahaan dan pemerintah, adapun sector-sektor tersebut antara lain: Dalam Bursa Efek terdapat tiga sektor yaitu : (a) Sektor Utama antara lain; Sektor pertanian, sektor pertambangan; (b) sektor 
industri manufaktur antara lain; sektor industri dasar dan kimia seperti logam dan sejenisnya, sektor industri barang konsumsi seperti makanan dana minuman; (c) sektor industri jasa antara lain; sektor propert, real estat dan kontruksi bangunan, sektor infrastruktur, utilitas \& transfortasi. Dalam sector transfortasi udara, industry penerbangan menjadi pemain kunci untuk mengembangkan sarana transfortasi itu sendiri. Indonesia Negara kepulauan yang sekarang banyak persaingan perusahaan transfortasi udara, baik berasal dari dalam Badan Usaha Milik Negara (BUMN) maupun swasta persaingan dengan perusahaan asing DLL.

Industri penerbangan memilki potensi untuk terus berkembang. Sebab Indonesia merupakan negara kepulauan terbesar di dunia yg memiliki lebih dari 100.000 pulau yang terbesar di sepanjang katulistiwa. Oleh karena itu, transportasi udara merupakan salah satu transportasi utama di negara ini. Semenjak tahun 2000, peraturan mengenai penerbangan di Indonesia mulai dilonggarkan, hal ini menyebabkan banyaknya maskapai-maskapai penerbangan baru di Indonesia.

Selain itu gencarnya pemerintah Indonesia yang mempromosikan pariwisata Indonesia membuat beberapa perusahaan penerbangan di Indonesia memilki kesempatan untuk terus berkembang dengan banyaknya traveler asing yang bepergian ke seluruh pelosok negeri menggunakan jasa transportasi udara. Terutama perusahaan penerbangan milik pemerintah, Garuda Indonesia yang kini tengah bangkit dan terus berkembang dari posisi yang hampir bangkrut menjadi salah satu penerbangan terbaik di Asia.

Untuk itu Garuda Indonesia pun memutuskan untuk Go Public dan menerbitkan saham perdananyapada 11 Februari 2011 lalu. Dengan harga jual saham per lembar yang ditetapkan oleh kementrian Badan Usaha Milik Negara (Kementrian BUMN) sebesar Rp 750. Harga saham perdana PT. Garuda Indonesia ini mengambil harga terendah dari yang ditawarkan yaitu $R p$ 750-Rp 1100. Analisis rasio keuangan dapat membantu para pelaku bisnis, pihak pemerintah dan para pemakai laporan keuangan lainnya menilai kondisi keuangan suatu perusahaan tidak terkecuali perusahaan penerbangan dimiliki pemerintah dalam memprediksi pertumbuhan laba perusahaan.

\section{B. RUMUSAN MASALAH}

Berdasarkan uraian latar
belakang masalah diatas,
permasalahan yang akan dibahas
dalam penelitian ini adalah :
"Bagaimana kinerja keuangan pada
PT. Garuda Indonesia (Persero) Tbk
pada periode 2013-2017"

\section{LANDASAN TEORI}

1) Pengertian Laporan Keuangan Menurut PSAK (2016:126) Laporan keuangan merupakan wujud pertanggungjawaban manajemen atas penggunaan sumber daya yang dipercayakan kepada mereka dalam mengelola suatu entitas dengan demikian laporan keuangan tidak dimaksudkan untuk tujuan khusus, misalnya dalam dalam rangka likuidasi entitasatau menentukan nilai wajar entitas untuk tujuan marger dan akuisisi.

Menurut Kasmir (2015:7) Laporan Keuangan adalah laporan yang menunjukkan kondisi keuangan perusahaan pada saat ini atau dalam suatu periode tertentu. Maksud laporan keuangan yang menunjukkan kondisi perusahaan saat ini adalah merupakan kondisi terkini. kondisi perusahaan 
terkini adalah keadaan keuangan perusahaan pada tanggal tertentu (untuk Laporan posisi keuangan) dan periode tertentu (untuk laporan laba rugi komprehensif). Biasanya laporan keuangan dibuat per periode, misalnya tiga bulan, atau enam bulan untuk kepentingan internal perusahaan. sementara itu, untuk laporan lebih luas dilakukan satu tahun sekali. Di samping itu, dengan adanya laporan keuangan, dapat diketahui posisi perusahaan terkini setelah manganalisis laporan keuangan tersebut dianalisis .Menurut Brigham (2013:84) "Laporan keuangan adalah beberapa lembar kertas dengan angka-angka yang tertulis diatasnya, tetapi penting juga untuk memikirkan aset-aset myata yang berada dibalik angka tersebut."

\section{2) Tujuan Laporan Keuangan} Menurut PSAK (2016:126) Tujuan laporan keuangan adalah memberikan informasi mengenai posisi keuangan, kinerja keuangan, dan arus kas entitas yang bermanfaat bagi sebagian besar pengguna laporan keuangan dalam membuat keputusan ekonomi.

Menurut Kasmir (2015:10), laporan keuangan bertujuan untuk memberikan informasi keuangan suatu perusahaan, baik pada saat tertentu maupun pada periode tertentu. Laporan keuangan juga dapat disusun secara mendadak sesuai kebutuhan perusahaan maupun secara berkala, jelasnya adalah laporan keuangan mampu memberikan informasi keuangan kepada pihak dalam dan luar perusahaan yang yang memiliki kepentingan terhadap perusahaan.

Tujuan laporan keuangan itu sendiri ialah menyajikan informasi tentang posisi keuangan seperti laporan posisi keuangan, aktiva, hutang dan modal pada periode tertentu dengan kata lain tujuan laporan keuangan yaitu menunjukkan kinerja perusahaan dalam mendapatkan atau menghasilkan pendapatan yang optimal. Laporan keuangan ini tidak serta merta hanya digunakan dan diketahui oleh pihak perusahaan tetapi ada pihak-pihak yang menggunakan laporan keuangan perusahaan.

Menurut Fahmi (2013:5) tujuan laporan keuangan adalah "Memberikan informasi kepada pihak yang membutuhkan tentang kondisi suatu perusahaan dari sudut angka-angka dalam satuan moneter".

\section{3) Komponen Laporan Keuangan}

Menurut PSAK (2016:120) untuk mencapai tujuan, laporan keuangan yang lengkap terdiri dari komponen berikut:

a. Laporan posisi keuangan (Neraca) pada akhir periode.

b. Laporan laba rugi komprehensif selama periode.

c. Laporan perubahan ekuitas selama periode.

d. Laporan arus kas selama periode.

e. Catatan atas laporan keuangan, berisi ringkasan kebijakan akuntansi penting dan informasi penjelasan lain, dan informasi komparatif mengenai periode terdekat sebelumnya,serta

f. Laporan posisi keuangan pada awal periode komparatif, yang disajikan ketika antitas menerapkan suatu kebijakan akuntansi secara retrospektif atau membuat penyajian kembali pospos laporan keuangan, atau ketika entitas mereklasifikasi pospos dalam laporan keuangannya.

Laporan keuangan menggambarkan pos-pos keuangan perusahaaan yang diperoleh dalam 
suatu periode (Kasmir, 2015:6). Dalam praktiknya dikenal beberapa macam laporan keuangan seperti :

1. Laporan posisi keuangan (Neraca)

2. Laporan laba rugi komprehensif

3. Laporan arus kas

4. Laporan perubahan ekuitas

5. Catatan atas laporan keuangan

\section{4) Jenis Laporan Keuangan}

Menurut PSAK (2016:77)

Terdapat 5 jenis pokok laporan keuangan, yaitu

1. Aset,

2. Liabilitas

3. Ekuitas

4. Laporan posisi keuangan (Neraca)

5. Pendapatan dan beban yang merupakan unsur laporan laba rugi

Secara Umum ada lima macam jenis laporan keuangan yang biasadisusun, (Kasmir, 2015:28) :

1. Laporan posisi keuangan (Neraca)

2. Laporan laba rugi komprehensif

3. Laporan perubahan ekuitas

4. Laporan arus kas

5. Catatan atas laporan keuangan;

Sedangkan Menurut Harahap (2010:106) Jenis laporan keuangan utama dan pendukung :

1. Dana disini dimuat sumber dan pengeluaran perusahaan selama satu periode; Daftar Laporan posisi keuangan yang menggambarkan posisi keuangan perusahaan pada suatu tanggal tertentu.

2. Perhitunga Laba / Rugi komprehensif yang menggambarkan jumlah hasil biaya dan Laba / Rugi perusahaan pada suatu periode tertentu.
3. Laporan sumber dan penggunaan.

4. Laporan arus kas disini digambarkan sumber dan penggunaan kas dalam suatu periode.

5. Laporan harga pokok produksi yang menggambarkan berapa dan unsur apa yang diperhitungkan dalam harga pokok produksi suatu barang .Dalam hal tersebut harga pokok produksi (HPPd) ini disatukan dalam laporan harga pokok penjualan (HPPj).

$\mathrm{HPPj}=\mathrm{HPPj}+$ persediaan awal persediaan akhir

Harga pokok penjualan adalah harga pokok produksi ditambah dengan persediaan barang awal dikurangi persediaan barang akhir.

6. Laporan laba ditahan, menjelaskan posisi laba ditahan yang tidak dibagikan kepada pemilik saham.

7. Laporan perubahan modal, menjelaskan perubahan posisi modal baik saham dalam PT atau modal dalam perusahaan perseroan.

8. Dalam suatu kajian dikenal laporan kegiatan keuangan laporan ini menggambarkan transaksi laporan keuangan perusahaan yang memengaruhi kas atau ekuivalen kas. laporan ini jarang digunakan. laporan ini merupakan rekomendasi.

\section{5) Sifat Laporan Keuangan}

Menurut Kasmir (2015:11) pencatatan yang dilakukan dalam penyusunan laporan keuangan harus dilakukan dengan kaidah-kaidah yang berlaku demikian pula dalam hal penyusunan laporan keuangan disadarkan kepada sifat laporan 
keuangan itu sendiri. dalam praktiknya sifat laporan keuangan dibuat

1. Bersifat historis

2. menyeluruh

Bersifat historis artinya bahwa laporan keuangan dibuat dan disusun dari data masa lalu atau masa yang sudah lewat dari masa sekarang. Misalnya laporan keuangan disusun berdasarkan data satu atau dua atau bebrapa tahun kebelakang (tahun atau periode sebelumnya).

Kemudian bersifat menyeluruh maksudnya laporan keuangan dibuat selengkap mungkin. Artinya laporan laporan keuangan disusun sesuai dengan standar yang telah ditetapkan. pembuatan atau penyusunan yang hanya sebagian -sebagian (tidak lengkap) tidak akan memberikan informasi yang lengkap tentang keuangan suatu perusahaan.

Sedangkan Menurut Harahap (2010:127) Akuntansi keuangan memberikan informasi yang bersifat baku, terstandar dan bertujuan umum (general purpose). format informasinya sudah memiliki pola yang ditetapkan lembaga resmi yang berhak menyusun standar pelaporan akuntansi. Di Indonesia disebut SAK (standar akuntansi keuangan) dikeluarkn oleh IAI diAmerika disebut GAAP (general accepted accounting principle) yang dikeluarkan oleh financial accounting standard board (FASB) dengan nama FASB statement. Laporan dari akuntansi keuangan ini dilindungi dan diawasi oleh pemerintah karna menyangkut kepentingan umum. Laporan yang dikeluarkan akuntansi keuangan dimanfaatkan masyarakat dalam menilai saham suatu perusahaan.

Oleh karna itulah tidak bisa begiatu saja dikeluarkan laporan yang terpercaya sebelum ada proses penyaksian (attest function) atau audit yang dilakukan oleh akuntan public terdaftar yang juga kehadirannya diatur oleh pemerintah. Di Indonesia dimonitor oleh Departemen keuangan dan IAI.

\section{6) Analisis Kinerja Keuangan}

Kinerja keuangan diukurdan dievaluasi untuk menentukan sejauh mana keberhasilan atas kinerja tersebut dapat mencapai suatu tujuan tertentu. Dua aspek yang sering digunakan dalam menilai kinerja adalah efektivitas dan efensiensi. efektivitas mencerminkan hubungan output dengan tujuan tertentu, sedangkan efesiensi mengganbarkan hubungan input dan output.

\section{7) Definisi Kinerja Keuangan}

Secara Umum kinerja keuangan merupakan gambaran tentang kondisi keuangan suatu perusahaan yang dinilai dengan alat-alat analisis keuangan, sehingga dapat diketahui mengenai baik buruknya keadaan keuangan suatu perusahaan yang mencerminkan keberhasilan perusahaan dalam mencapai tujuannya.

Menurut Munawir (2010:30) kinerja keuangan merupakan satu diantara dasar penilaian mengenai kondisi keuangan perusahaan yang dilakukan berdasarkan analisa terhadap rasio keuangan perusahaan

Menurut Fahmi (2012:2) kinerja keuangan adalah suatu analisis yang dilakukan untuk melihat sejauh mana suatu perusahaan telah melaksanakan dengan menggunakan aturan-aturan pelaksanaan keuangan secara baik dan benar, kinerja perusahaan merupakan satu gambaran tentang kondisi keuangan suatu perusahaan yang dianalisis dengan alat-alat analisis keuangan, sehingga dapat diketahui mengenai baik buruknya keadaan keuangan suatu perusahaan yang mencerminkan prestasi kerja 
dalam priode tertentu. Hal ini sangat penting agar sumber daya digunakan secara optimal dalam menghadapi perubahan lingkungan.

Kemudian menurut Jumingan (2011:239) Kinerja keuangan yaitu "Merupakan gambaran kondisi keuangan pada suatu periode tertentu baik menyangkut aspek penghimpunan dana maupun penyaluran dana yang biasanya diukur dengan indikator kecukupan modal, likuiditas dan profitabilitas.

\section{8) Tujuan dan Manfaat Kinerja Keuangan}

Pengukuran kinerja keuangan digunakan perusahaan untuk melakukan perbaikan diatas kegiatan opersionalnya agar dapat bersaing dengan perusahaan lain. Analisis kinerja keuangan merupakan proses pengkajian secara kritis terhadap review data, menghitung, mengukur, menginterfrestasi, dan memberi solusi terhadap keuangan perusahaan pada suatu periode tertentu.

Menurut Munawir (2012;31) menyatakan bahwa tujuan dari pengukuran kinerja keuanagn perusahaan adalah: (a) mengetahui tingkat likuiditas; (b) mengetahui tingkat solvabilitas; (c) mengetahui tingkat rentabilitas; (d) mengetahui tingkat stabilitas.

\section{9) Analisis Laporan Keuangan}

Menganalisis laporan keuangan berarti mengevaluasi tiga karakteristik keuangan dari perusahaan yaitu likuiditas, profitabilitas, dan solvabilitasnya. Likuiditas dari perusahaan sangat penting bagi kreditor jangka pendek untuk mengevaluasi kemampuan perusahaan dalam melunasi pinjamannya. Berbeda dengan kreditor jangka panjang seperti pemegang obligasi melihat pada pengukuran profitabilitas dan solvabilitas yang mengindikasikan kemampuan pinjaman untuk bisa bertahan selama periode waktu yang panjang.

\section{0) Definisi Analisis Laporan Keuangan}

Menurut Kasmir (2015:66) setelah laporan keuangan disusun berdasarkandata yang relevan, serta dilakukan dengan prosedur akuntansi dan penilaian yang benar, akan terlihat kondisi keuangan perusahaan yang sesungguhnya. kondisi keuangan yang dimaksud adalah diketahui nya berapa jumlah harta (kekayaan), kewajiban (utang) serta modal (ekuitas) dalam Laporan posisi keuangan yang dimiliki, kemudian juga akan diketahui jumlah pendapatan yang diterima dan jumlah biaya yang dikeluarkan selama periode tertentu

Menurut Subramanyam (2014:4) Analisis laporan keuangan (financial statement analysis) adalah aplikasi dari alat dan teknik analitis untuk laporan keuangan bertujuan umum dan data-data yang berkaitan untuk menghasilkan estimasi dan kesimpulan yang bermanfaat dalam analisis bisnis.

Harahap (2010:190) menyatakan bahwa "Analisis laporan keuangan adalah menguraikan pos-pos laporan keuangan menjadi unit informasi yang lebih kecil danmelihat hubungannya yang bersifat signifikan atau yang mempunyai makna antara satu dengan yang lain antara data kuantitatif maupun non kuantitatif dengan tujuan untuk mengetahui kondisi keuangan lebih dalam yang sangat penting dalam proses menghasilkan keputusan yang tepat".

\section{1) Tujuan dan Manfaat Analisis}

Kegiatan dalam analisis laporan keuangan dapat dilakukan dengan cara menentukan dan mengukur antara pos-pos yang ada dalam satu 
laporan keuangan. kemudian, analisis laporan keuangan juga dapat dilakukan dengan menganalisis laporan keuangan yang dimilki dalam satu periode. Disamping itu analisis laporan keuangan dapat dilakukan pula antara beberapa periode (misalnya tiga tahun).

Analisis laporan keuangan yang dilakukan untuk beberapa periode adalah menganalisis antara pos-pos yang ada dalam satu laporan dengan laporan yang yang lainnya. Hal ini dilakukan agar dapat lebih tepat dalam menilai kemajuan atau kinerja manajemen dan periode ke periode selanjutnya.

Ada beberapa tujuan dan manfaat bagi berbagai pihak dengan adanya analisis laporan keuangan. Secara Umum dikatakan bahwa tujuan dan manfaat analsis laporan keuangan ialah (Kasmir, 2015:68).

1. Untuk mengtahui posisi keuangan perusahaan dalam satu periode tertentu, baik harta, kewajiban, modal, maupun hasil usaha yang telah dicapai untuk beberapa periode.

2. untuk mengetahui kelemahankelemahan apa saja yang menjadi kekurangan perusahaan

3. untuk mengetahui kekuatankekuatan yang dimiliki.

4. untuk mengetahui langkahlangkah perbaikan apa saja yang perlu dilakukan kedepan yang berkaitan dengan posisi keuangan perusahaan saat ini.

5. untuk melakukan penilaian kinerja manajemen ke depan apakah perlu penyegaran atau tidak karna sudah dianggap berhasil atau gagal.

6. dapat juga digunakan sebagai pembanding dengan perusahaan sejenis tentang hasil yang mereka capai.

\section{2) Analisis Rasio}

Menurut Kasmir (2015:104) Rasio yang digunakan untuk menilai kinerja keuangan ada 4:

1. Rasio Likuiditas

2. Rasio solvabilitas

3. Rasio aktivitas (activity ratio)

4. Rasio profitabilitas

Sedangkan Menurut Harahap (2010:297) rasio keuangan adalah angka yang diperoleh dari hasil perbandingan dari satu pos laporan keuanga dengan pos lainnya yang mempunyai hubungan yang relevan dan signifikan (berarti), produksi dengan total penjualan,dan sebagainya. Teknik ini sangat lazim digunakan para analisis keuangan. Rasio keuangan sangat penting dalam melakukan analisis terhadap kondisi keuangan perusahaan. Adapun rasio keuangan yang digunakan adalah: rasio likuiditas, solvabilitas, profitabilitas / rentabilitas, rasio leverage, rasio aktivitas, rasio pertumbuhan, marked based (penilaian pasar), rasio produktivitas.

Jadi rasio keuangan merupakan kegiatan membandingkan angkaangka yang ada dalam laporan keuangan dengan cara membagi satu angka dengan angka lainnya. Perbandingan dapat dilakukan antara satu komponen dengan komponen dalam satu laporan keuangan. kemudian angka yang diperbandingkan dapat berupa angkaangka dalam satu periode maupun beberapa periode.

Menurut Munawir (2010:36) ada dua metode analisis yang digunakan oleh setiap penganalisa laporan keuangan, yaitu analisis Horizontal dan analisis vertikal. Analisis Horizontal (Dinamis) merupakan analisis yang dilakukan dengan membandingkan laporan keuangan untuk beberapa periode. Dari hasil analisis ini akan 
terlihat perkembangan perusahaan dari periode satu keperiode lainnya ,Analisis Vertikal (Statis) merupakan analisis yang dilakukan terhadap hanya satu periode laporan keuangan saja.analisis ini dilakukan antara pospos yang ada, dalam satu periode informasi diperoleh hanya satu periode saja dan tidak diketahui perkembangan dari periode ke periode

\section{3) Keterbatasan Analisis Rasio}

Menurut Kasmir (2015:118) untuk meminimalkan resiko kesalahan dalam membuat rasio keuangan, diperlukan prinsip kehati-hatian, setidaknya dengan tindakan kehati-hatian ini dapat membantu dalam menutupi kelemahan dari rasio keuangan tersebut.

Sedangkan Menurut Harahap (2010:298) Teknik ini juga memiliki beberapa keterbatasan yang harus disadari sewaktu penggunaannya agar kita tidak salah dalam pengguannnya. Adapun keterbatasan analisis rasio itu adalah:

1. Kesulitan dalam memilih rasio yang tepat yang dapat digunakan untuk kepentingan pemakainya.

2. Keterbatasan yang dimilki akuntansi atau laporan keuangan juga menjadi keterbatasan teknik ini seperti:

a. bahan perhitungan rasio atau lapran keuangan itu banyak mengandung taksiran dan judgment yang dapat dinilai bias atau subjektif.

b. nilai yang terkandung dalam laporan keuangan dan rasio adalah nilai perolehan (cost) bukan harga pasar.

c. klasifikasi dalam laporan keuangan bisa berdampak pada angka rasio

d. metode pencatatn yang tergambar dalam standar akuntansi bisa diterapkan berbeda oleh perusahaan yang berbeda.

3. Jika data untuk menghitung rasio tidak tersedia, akan menimbulkan kesulitan menghitung rasio.

4. Sulit jika data yang tersedia tidak sinkron.

5. dan perusahaan dibandingkan bisa saja teknik dan standar akuntansi yang dipakai tidak sama. oleh karnanya jika dilakukan perbandingan bisa menimbulkan kesalahan.

\section{4) Penggolongan Tingkat Kesehatan Perusahaan BUMN}

\section{a. Rasio Likuiditas}

Rasio ini menunjukkan kemampuan suatu perusahaan untuk memenuhi kewajiban jangka pendeknya secara tepat waktu.

1) Rasio Lancar (Current Ratio)

Rasio lancar merupakan rasio untuk mengukur kemampuan perusahaan dalam membayar kewajiban jangka pendek atau utang yang segera jatuh tempo pada saat ditagih secara keseluruhan.

Menurut BUMN:

Current Ratio $=\frac{\text { current asset }}{\text { current liabilities }} \times 100 \%$

Menurut ( Kasmir,2014:135) :

current Ratio $=\frac{\text { Aktiva lancar (current asset }}{\text { Utang lancar (current liabilities }}$

2. Rasio Kas (Cash Ratio)

Cash ratio merupakan alat yang digunakan untuk mengukur seberapa besar uang kas yang tersedia untuk membayar utang.

Menurut BUMN:

Rasio kas $=\frac{\text { Kas+bank+surat berharga jangka pendek }}{\text { Hutang lancar }} \times 100 \%$

Menurut (Kasmir,2014:139) :

Cash Ratio $=\frac{\text { kas }+ \text { Bank }}{\text { current liabilities }}$ 


\section{b. Rasio Profitabilitas}

Rasio Profitabilitas merupakan rasio untuk menilai kemampuan perusahaan dalam mencari keuntungan.

1) Return on Investment (ROI)

$\mathrm{ROI}$ merupakan suatu ukuran tentang efektivitas manajemen dalammengelola investasinya.

Menurut BUMN :

$R O I=\frac{\text { EBIT }+ \text { Penyusutan }}{\text { Modal usaha }} \times 100 \%$

Menurut (Kasmir,2014:202) :

$\mathrm{ROI}=\frac{\text { Earning after interest and tax }}{\text { Total assets }}$

2) Hasil Pengembalian Ekuitas (Return on Equity/ROE)

ROE merupakan rasio untuk mengukur laba bersih sesudah pajakdengan modal sendiri.

Menurut BUMN

$R O E=\frac{\text { Laba setelah pajak }}{\text { Modal sendiri }} \times 100 \%$

Menurut (Kasmir,2014:204) :

$\mathrm{ROE}=\frac{\text { Earning after interest and tax }}{\text { Equity }}$

c. Rasio Aktivitas

Rasio aktivitas merupakan rasio yang digunakan untuk mengukurefektivitas perusahaan dalam menggunakan aktiva yang dimilikinya atau dapat pula dikatakan rasio ini digunakan untuk mengukur tingkat efisiensi pemanfaatan sumber daya perusahaan.

1) Perputaran Sediaan (Inventory Turn Over)

Perputaran Sediaan merupakan rasio yang digunakan untuk mengukur berapa kali dana yang ditanam dalam sediaan ini berputar dalam suatu periode.

Menurut BUMN:

$\mathrm{pp}=\frac{\text { Total persediaan }}{\text { Total pendapatan Usaha }} \times 365$ hari
Menurut (Kasmir,2014:182) :

$I T O=\frac{\text { Hrga pokok barang yang dijual }}{\text { Sediaan }}$

2) Total Assets Turn Over(TATO)

Total Assets Turn

Overmerupakan rasio yang digunakan untukmengukur perputaran semua aktiva yang dimiliki perusahaan danmengukur berapa jumlah penjualan yang diperoleh dari rupiah aktiva.

Menurut BUMN:

TATO $=\frac{\text { Total pendapatan }}{\text { Capital employed }} \times 100 \%$

Menurut (Kasmir,2014:184):

TATO $=\frac{\text { Penjualan(sales) }}{\text { Total aktiva(total assets) }}$

3) Collection periods (CP)

Rumus:

Menurut BUMN:

$C P=\frac{\text { Total piutang usaha }}{\text { Total pendapatan usaha }} \times 365$ hari

4) Rasio Total modal sendiri terhadap total asset (TMS terhadap TA)

Rumus:

TMS terhadap TA=

$\frac{\text { Total modal sendiri }}{\text { Total asset }} \times 100 \%$

Penggolongan tingkat kinerja keuangan berdasarkan pada surat Keputusan Menteri BUMN Nomor: KEP-100/MBU/2002

Penilaian tingkat kesehatan BUMN digolongkan menjadi :

\section{A. sehat yang terdiri dari:}

(a) AAA apabila total (TS) lebih besar dari 95

(b) AA apabila $80 \leq T S \leq=95$;

(c) A apabila $65 \leq \mathrm{TS} \leq=80$;

B. kurang sehat, yang terdiri dari:

(a) BBB apabila $50 \leq T S \leq=65$;

(b) BB apabila $40 \leq \mathrm{TS} \leq=50$;

(c) B apabila $30 \leq \mathrm{TS} \leq=40$; 
C. Tidak sehat, yang terdiri dari:

A. CCC apabila $20 \leq T S \leq=30$;

B. CC apabila $10 \leq \mathrm{TS} \leq=20$;

C. C apabila $T S \leq T S \leq=10$;

15) Kerangka Berpikir

Dalam buku Sugiyono (2016:60) seorang peneliti harus menguasai teori-teori ilmiah sebagai dasar bagi argumentasi dalam menyusun kerangka pemikiran yang membuahkan hipotesis kerangka pemikiran ini merupakan penjelasan sementara terhadap gejala-gejala yang menjadi objek permasalahan.

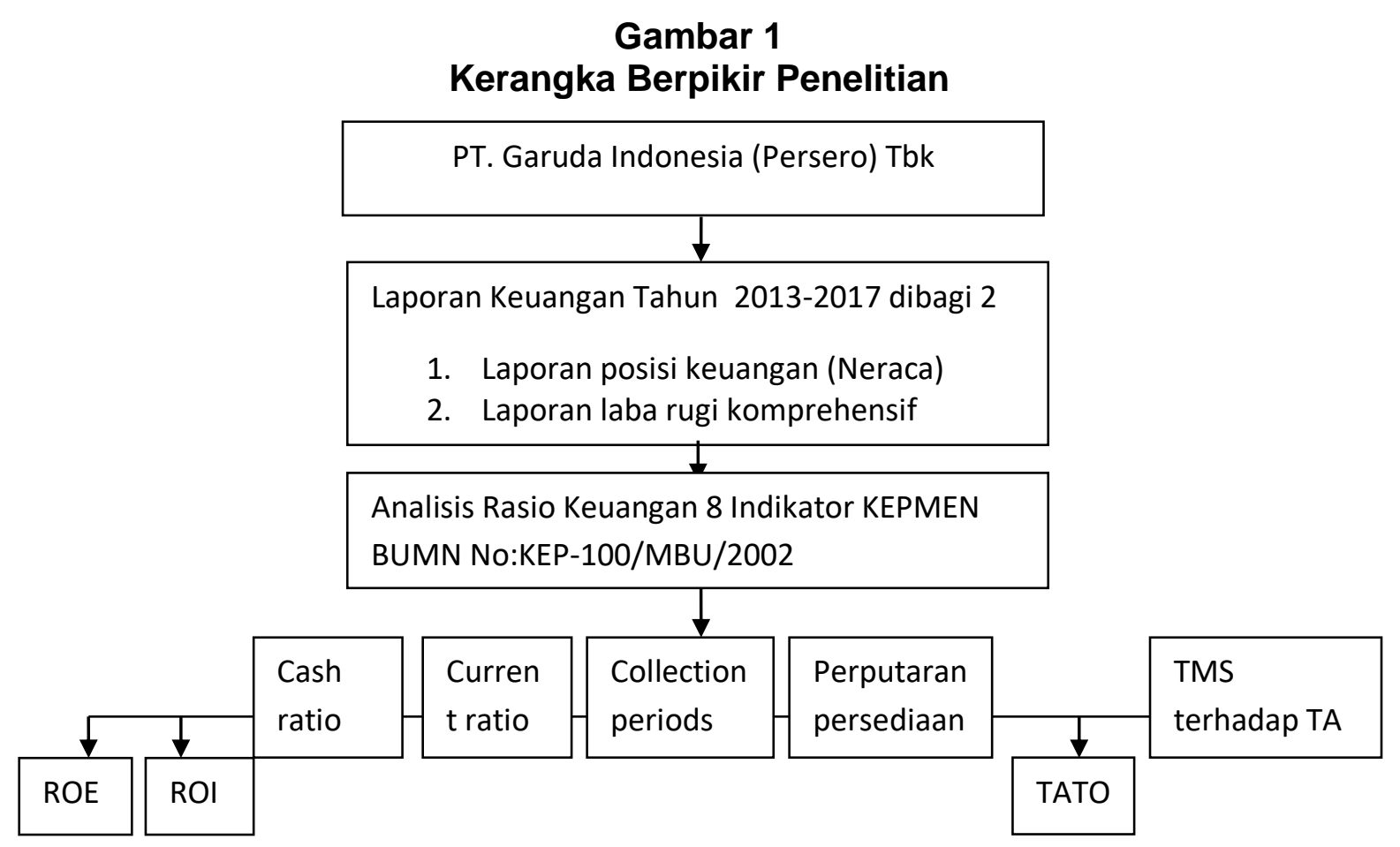

\section{METODE PENELITIAN}

Menurut Sugiyono (2016:2) metode penelitian diartikan sebagai cara ilmiah untuk mendapatkan data dengan tujuan dan keuangan tertentu, cara ilmiah berarti kegiatan peneliti itu didasarkan pada ciri-ciri keilmuan yaitu rasional, empiris dan sistematis.

Metode penelitian yang digunakan oleh penulis metode deskriptif dan kuantitatif yaitu metode yang menganalisis dan mendeskripsikan data-data laporan keuangan untuk menentukan kategori kesehatan perusahaan.

\section{E. POPULASI DAN SAMPEL \\ 1) Populasi}

Menurut Wiratna Sujarweni (2014:65) Populasi adalah keseluruhan jumlah yang terdiri atas obyek atau subyek yang mempunyai karakteristik dan kualitas tetentu yang ditetapkan oleh peneliti untuk diteliti dan kemudian ditarik kesimpulannya.

Berdasarkan pengertian diatas, Populasi dalam penelitian ini adalah laporan keuangan perusahaan BUMN PT. Garuda Indonesia (Persero) Tbk yang terdaftar dibursa efek Indonesia.

\section{2) Sampel}

Sampel adalah bagian dari populassi yang ingin diteliti oleh peneliti Menurut Wiratna Sujarweni (2014:65) "Sampel adalah bagian dari sejumlah karakteristik yang dimiliki 
oleh populasi yang digunakan untuk penelitian. bila populasi besar.Jadi peneliti mengambil sampel dalam Laporan posisi Keuangan(Neraca) dan laba rugi pada Perusahaan PT.Garuda Indonesia (Persero)Tbk dari periode 2013-2017.

\section{F. TEKNIK PENGUMPULAN DATA}

Teknik pengumpulan data dalam penelitian ini terdapat data sekunder dan dokumentasi data yang telah ada di perusahaan seperti struktur organisasi, sejarah perusahaan dan laporan keuangan dari tahun 20132017

\section{G. TEKNIK ANALISIS DATA}

Teknik analisis data adalah suatu teknik yang digunakan sebagai alat bantu bagi peneliti untuk mengambil suatu kesimpulan atas sejumlah data penelitianyang telah terkumpul.

Metode analisis data yang digunakan dalam penelitian ini adalah analisis kuantitatif dan Deskriptif
Adapun metode yang digunakan menggunakan metode vertikal dan Horizontal. Menurut Kasmir (2012:69) :

1. Analisis Horizontal (Dinamis)

Merupakan analisis yang dilakukan dengan membandingkan laporan keuangan untuk beberapa periode. Dari hasil analisis ini akan terlihat perkembangan perusahaan dari periode satu keperiode lainnya

2. Analisis Vertikal (Statis)

Merupakan analisis yang dilakukan terhadap hanya satu periode laporan keuangan saja.Analisis ini dilakukan antara pos-pos yang ada,dalam satu periode informasi diperoleh hanya satu periode saja dan tidak diketahui perkembangan dari periode ke periode

Indikator yang dinilai dan masingmasing bobotnya. Dalam penilaian aspek keuangan ini,indikator yang dinilai dan masing-masing bobotnya adalah:

TABEL 1

Daftar Indikator dan Bobot Aspek Keuangan

BUMN Infrastruktur dan Non Infrastruktur

\begin{tabular}{|l|c|c|}
\hline \multicolumn{1}{|c|}{ Indikator } & Bobot & Bobot \\
\cline { 2 - 3 } & Infrastruktur & $\begin{array}{c}\text { Non } \\
\text { infrastruktur }\end{array}$ \\
\hline 1. Imbalan kepada pemegang saham (ROE) & 15 & 20 \\
\hline 2. Imbalan investasi & 10 & 15 \\
\hline 3. rasio kas & 3 & 5 \\
\hline 4. Rasio lancar & 4 & 5 \\
\hline 5. Collection periods & 4 & 5 \\
\hline 6. Perputaran persediaan & 4 & 5 \\
\hline 7. Perputaran total asset & 4 & 5 \\
\hline 8. Rasio modal sendiri terhadap total aktiva & 6 & 10 \\
\hline Total Bobot & 50 & 70 \\
\hline
\end{tabular}

Sumber: Surat Keputusan Menteri BUMN Nomor: KEP-100/MBU/2002 
H. HASIL DAN PEMBAHASAN

1) Hasil Penelitian

a. Analisis Rasio

Analisis Kinerja Berdasarkan SK Menteri BUMN KEP-100/MBU/2002 meliputi tiga aspek yaitu aspek keuangan, aspek operasional, dan aspek administrasi. Analisa dalam penelitian ini hanya terbatas pada aspek keuangan saja. Tujuan dan sasarannya adalah untuk mengetahui kondisi kesehatan KINERJA KEUANGAN PT Garuda Indonesia (Persero) Tbk Periode 2013-2017.

\section{b. Kinerja Keuangan}

Kinerja keuangan perusahaan secara keseluruhan diukur berdasarkan delapan indikator yang telah dihitung pada sub-bab sebelumnya. Dari penilai setiap indikator yang digunakan untuk mengukur kinerja keuangan perusahaan BUMN, berikut adalah kinerja keuangan PT Garuda Indonesia (Persero)Tbk sebelum diskor berdasarkan KEP-100/MBU/2002.

Tabel 2

Kinerja Keuangan Perusahaan PT.Garuda,Tbk hitungan hasil rasio

\begin{tabular}{|l|c|c|c|c|c|}
\hline Indikator penilaian & 2013 & 2014 & 2015 & 2016 & 2017 \\
\hline $\begin{array}{l}\text { Imbalan kepada } \\
\text { pemegang saham(ROE) }\end{array}$ & $\mathbf{1} \%$ & $(40.58 \%)$ & $8,20 \%$ & $0.93 \%$ & $(72.41 \%)$ \\
\hline Imbalam investasi(ROI) & $\mathbf{0 . 3 8 \%}$ & $(12.00 \%)$ & $2.36 \%$ & $0.25 \%$ & $(18.04 \%)$ \\
\hline Rasio kas & $\mathbf{4 8 . 3 0 \%}$ & $35.61 \%$ & $43.48 \%$ & $37.01 \%$ & $15.97 \%$ \\
\hline Rasio lancar & $\mathbf{8 3 . 2 5} \%$ & $66.47 \%$ & $84.28 \%$ & $74.52 \%$ & $51.34 \%$ \\
\hline Cillection periods & $\mathbf{1 5 h a r i}$ & 12 hari & 13 hari & 20 hari & 24 hari \\
\hline Perputaran persediaan & 9 hari & 8 hari & 9 hari & 10 hari & 11 hari \\
\hline Perputaran total asset & $129 \%$ & $161 \%$ & $115 \%$ & $103 \%$ & $111 \%$ \\
\hline $\begin{array}{l}\text { Rasio modal sendiri thd } \\
\text { total aktiva }\end{array}$ & $37.82 \%$ & $29.56 \%$ & $28.72 \%$ & $27.02 \%$ & $24.91 \%$ \\
\hline
\end{tabular}

Tabel diatas menunjukkan perkembangan kedelapan indikator dalam nilai rasio yang dihitungdengan rumusyang telah ditetapkan pada KEP100/MBU/2002.
Pada lima tahun tersebut, perusahaan mengalami penurunan kinerja yang dapat dilihat pada tabel dibawah ini:

Tabel 3

Kinerja Keuangan PT.Garuda,Tbk dalam bentuk skor

\begin{tabular}{|l|l|l|l|l|l|l|}
\hline Indikator penilaian & Bobot & 2013 & 2014 & 2015 & 2016 & 2017 \\
\hline $\begin{array}{l}\text { Imbalan kpd pemegang } \\
\text { saham(ROE) }\end{array}$ & 20 & 2 & 0 & 12 & 2 & 0 \\
\hline Imbalan investasi(ROI) & 15 & 2 & 1 & 3 & 2 & 1 \\
\hline Rasio kas & 5 & 5 & 5 & 5 & 5 & 3 \\
\hline Rasio lancar & 5 & 0 & 0 & 0 & 0 & 0 \\
\hline Collection periods & 5 & 5 & 5 & 5 & 5 & 5 \\
\hline Perputaran persediaan & 5 & 5 & 5 & 5 & 5 & 5 \\
\hline Perputaran total asset & 5 & 5 & 5 & 4,5 & 4 & 4,5 \\
\hline Rasio modal sendiri thd total aktiva & 10 & 10 & 7,25 & 7,25 & 7,25 & 7,25 \\
\hline Total penilaian & 70 & 34 & 28,25 & 41,75 & 30,25 & 25,75 \\
\hline
\end{tabular}


Tabel diatas menunjukkan Kinerja keuangan kedelapan indikator setelah diubah dalam satuan skor yang telah ditetapkan pada KEP100/MBU/2002.

\section{HASIL PENELITIAN DAN PEMBAHASAN}

Hasil analisis terhadap data keuangan baik analisis rasio profitabilitas,Likuiditas,Aktivitas dan Solvabilitas Berdasarkan SK Menteri BUMN KEP-100/MBU/2002 untuk menilai kinerja PT Garuda Indonesia (Persero) Tbk Tahun 2013sampai tahun 2017.

\section{1) Kinerja Keuangan PT Garuda Indonesia (Persero)Tbk tahun 2013}

Sesuai

KEP-100/MBU/2002 perusahaan dinyatakan kurang sehat dengan penilaian"B" dimana total skor yang diperoleh dari aspek keuangan tahun 2011adalah 34 dengan standar penilaian $30 \leq \mathrm{TS} \leq=40$

Pada tahun 2013 penilaian "B" didapatkan karena menurunnya kinerja pada rasio ROE,ROI,Rasi Lancar. Ketiga rasio ini menunjukkan hasil dengan nilai Jauh dibawah standar, dimana seharusnya rasio ini mencapai nilai tertingginya. Rasio ROE, ROI, Lancar mengalami penurunan kinerja disebabkan oleh menurunnya nilai total laba, modal kerja dankewajiban jangka pendek secara drastis dari tahun sebelumnya.

\section{2) Kinerja Keuangan PT Garuda Indonesia (Persero)Tbk tahun 2014}

Sesuai KEP-100/MBU/2002 perusahaan dinyatakan Tidak sehat denga penilaian "CCC" dimana total skor yang diperoleh dari aspek keuangan tahun 2014 adalah 28,25 dengan standar penilaian $20 \leq \mathrm{TS} \leq=30$;
Pada tahun 2014 penurunan kinerja disebabkan oleh semua rasio yang mencapai skor terendah namun pada beberapa rasio hasilnya sangat signifikan yaitu pada rasio kas, perputaran piutang,perputaran persediaan,perputaran total asset ,mencapai nilai skor tertinggi.

\section{3) Kinerja Keuangan PT Garuda Indonesia (Persero)Tbk tahun 2015}

Sesuai KEP-100/MBU/2002

perusahaan dinyatakan kurang sehat dengan penilaian "BB" dimana total skor yang diperoleh dari aspek keuangan tahun 2015 adalah 41,75 dengan standar penilaian $40 \leq \mathrm{TS} \leq=50$;

Pada tahun 2015 penurunan kinerja disebabkan oleh semua rasio yang tidak mencapai skor tertimgginya namun pada beberapa rasio penurunan hasilnya sangat signifikan yaitu pada rasio kas,perputaran persediaan, perputaran total asset. Nilai rasio kas mengalami penurunan disebakan kewajiban lancar dari tahun ketahun terus meningkat drastis meskipun nilai kas dan setara kas mengalami peningkatan namun tidak sebanding dengan peningkatan hutang lancar dan perputaran persediaan dibanding tahun sebelumnya mengalami peningkatan namun peningkatan yang ada tidak mencapai skor tertinggi dimasing-masing rasio. Sehingga peningkatan tersebut hanya menambah total bobot dan meningkatkan kinerja keuangan dari tahun sebelumnya tetapi masih berstatus kurang sehat atau "B"

\section{4) Kinerja Keuangan PT Garuda Indonesia (Persero)Tbk tahun 2016 \\ Sesuai \\ KEP-100/MBU/2002}

perusahaan dinyatakan tidak sehat dengan nilai "B" dimana total skor yang diperoleh dari aspek keuangan tahun 
2016 adalah 30,25dengan standar penilaian $30<\mathrm{TS}<=40$

Pada tahun 2016 penurunan kinerja keuangan disebabkan oleh beberapa rasio yang tidak mencapai skor tertingginya namun pada bebrapa rasio penurunan hasilnya sangat signifikan yaitu pada rasio ROE,ROI, Lancar, Nilai rasio lancar mengalami penurunan disebakan kewajiban lancar dari tahun ketahun terus meningkat.

\section{5) Kinerja Keuangan PT Garuda Indonesia (Persero)Tbk tahun 2017}

Sesuai KEP-100/MBU/2002 persahaan dinyatakan tidak sehat dengan penilaian "CCC" dimana total skor yang diperoleh dari aspek keuangan tahun 2017 adalah 25,75 dengan standar penilaian $20<\mathrm{TS}<=30$

Pada tahun 2017 penilaian CCC didapatkan karena menurunnya kinerja pada ROE,ROI,rasio kas, lancar, karena ke lima indikator tersebut mencapai bobot skor terendah.

\section{J. SIMPULAN DAN SARAN}

\section{1) Kesimpulan}

Dari hasil penelitian dan pembahasan dapat disimpulkan bahwa dari keselutuhan perhitungan rasio dan perhitungan skor untuk menilai kinerja keuangan PT Garuda Indonesia (Persero) Tbk Berdarakan KEP/100/MBU/2002 :

a. Pada tahun 2013 menunjukkan kinerja perusahaan yang kurang sehat,Sesuai

KEP100/MBU/2002

perusahaan dinyatakan kurang sehat dengan penilaian "B" dimana total skor yang diperoleh dari aspek keuangan tahun 2013 adalah 34 dengan standar penilaian $30 \leq \mathrm{TS} \leq=40$. Kemudian pada tahun 2014 perusahaan dinyatakan tidak sehat dengan penilaian "CCC" sama dengan tahun sebelumnya dimana total skor yang diperoleh dari aspek keuangan tahun 2014 adalah 28,25 dengan standar penilaian $20 \leq T S \leq=30$;.

Sedangkan pada tahun 2015 perusahaan dinyatakan kurang sehat dengan penilaian "BB" dimana total skor yang diperoleh dari aspek keuangan tahun 2013 adalah 41,75 dengan standar penilaian $\quad 40 \leq T S \leq=50$;. Selanjutnya pada tahun 2016 perusahaan dinyatakan tidak sehat dengan nilai " $B$ " dimana total skor yang diperoleh dari aspek keuangan tahun 2014 adalah 30,25 dengan standar penilaian $30<\mathrm{TS}<=40$. Tahun 2017 perusahaan dinyatakan tidak sehat penilaian "CCC" dimana total skor yang diperoleh dari aspek keuangan tahun 2015 adalah 25,75 dengan standar penilaian $20<\mathrm{TS}<=30$.

b. Secara keseluruhan dalam kurun waktu 5 tahun yaitu pada tahun 2013-2017 penilaian kinerja keuangan PT Garuda Indonesia (Persero) Tbk mengalami penurunan kinerja keuangannya masih dalam kondisi Tidak baik tingkat kesehatan kinerja keuangan Perusahaan.

\section{2) Saran}

a. PT Garuda Indonesia (Persero) Tbk diharapkan mampu meningkatkan Pendapatan dan efisiensi dalam mengelolah aset perusahaan, baik aset lancar dan aset tetap,juga menekan hutang lancar dan menarik para investor untuk menanamkan modalnya.

b. PT Garuda Indonesia (Persero) Tbk diharapkan mampu meningkatkan kesehatan keuangannya agar dapat memperoleh predikat sehat 
dengan dengan minimal kategori A dengan meningkatkan kinerja keuangannya karena sebagai perusahaan BUMN satu-satunya dimiliki pemerintah dibidang penerbangan.

c. Penelitian ini hanya sebatas pada aspek keuangan untuk menilai tingkat kesehatan perusahaan BUMN karena terbatasnya data yang diperoleh sehingga untuk penelitian selanjutnya diharapkan dapat menggunakan aspek data Operasional perusahaan sehingga penelitian ini analisis hasilnya lebih lengkap.

\section{DAFTAR PUSTAKA}

Annual Report, PT. Garuda Indonesia www.Garuda-Indonesia

Brigham, Eugene F dan Houston, Joel F. 2013. Dasar-dasar Manajemen keuangan. Edisi 11 Buku 2 Jakarta: Salemba Empat

Fahmi.2012. Analisis Laporan Keuangan, Cetakan Ke Dua. Bandung : Alfabeta

2013. Analisis Laporan Keuangan. Bandung : Alfabeta

Harahap.2010.Analisis Kritis atas Laporan

Keuangan.PT.Rajagrafindo

Persada: Jakarta

IAI, 2016. Akuntansi Keuangan Berdasarkan SAK berbasis IFRS. Jakarta. Edisi kedua
Jumingan, 2011. Analisis Laporan Keuangan. Jakarta : Bumi Aksara

Kasmir, 2012. Analisis Laporan Keuangan. PT. Rajagrafindo Persada : Jakarta Edisi kelima 2014. Analisis Laporan Keuangan. PT. Rajagrafindo Persada : Jakarta Edisi ketujuh

.2015. Analisis Laporan Keuangan. PT. Rajagrafindo Persada : Jakarta Edisi kedelapan

Keputusan Menteri Badan Usaha Milik Negara.KEP-100/MBU/2002

Munawir, 2010. Analisis Laporan Keuangan. Yogyakarta : Liberty

.2012. Analisis Laporan Keuangan. Yogyakarta Liberty

Subramanyam, K. R dan John J. Wild. 2014. Analisis Laporan Keuangan. Penerjemah Dewi Y. Jakarta : Salemba Empat.

Sugiyono, 2016. Metode Penelitian Kuantitatif, Kualitatif dan R\&D. ALFABETA : Bandung

Wiratna Sujarweni. 2014. MetodePenelitian. Pustaka Baru Press. Yogyakarta

www.Idx.co.id.diakses 20 Maret 2017 